\title{
The Extent of Language Naturalness in the Translation of Children's Storybooks Produced by Novice Translators in Ganesa Library
}

\author{
Nur Saptaningsih ${ }^{1}$, Ardianna Nuraeni $^{2}$, Agus Dwi Priyanto ${ }^{3}$, Intan Mustika Sari ${ }^{4}$, Yanuarria \\ Kukuh Perwira ${ }^{5}$ \\ \{nursaptaningsih@staff.uns.ac.id ${ }^{1}$, ardianna_n@staff.uns.ac.id ${ }^{2}$, apriyanto@staff.uns.ac.id ${ }^{3}$, \\ intanmustikasari65@gmail.com $\left.{ }^{4},\right\}$ \\ English Diploma Program, Sekolah Vokasi, Universitas Sebelas Maret ${ }^{12345}$
}

\begin{abstract}
Ganesa Library is a public reading center that provides thousands of English storybooks for readers. Being aware of the target readers' limitation in understanding English stories, the library welcomes university students in Solo and surrounding areas to translate the storybooks into Indonesian. Translating children's storybooks is challenging because message, language style, and readability need serious attention. Although the students' translation has facilitated many readers, the translation quality needs thorough evaluation since the translators are novice translators with limited competence. This rationale has triggered the researchers to further examine the language naturalness in the translation of English children's storybooks into Indonesian produced by intern students and the factors contributing to the level of naturalness. This qualitative descriptive study was carried out through textual analysis of the translation results. The findings show that most of the translation falls into less natural and unnatural categories, and this is attributable to both linguistic and cultural aspects.
\end{abstract}

Keywords: naturalness, translation, children storybooks, novice translators, Ganesa Library

\section{Introduction}

Children literature is a literature that is produced and intended for or enjoyed by children [1]. This type of literature is not only about children and their life, but also revolves anything, whether human life or the life of animals, plants, other creatures, including creatures from other worlds [2]. Further, whatever the content is, children stories must depart from children's points of views and within the reach of children's emotional understanding and thought.

Children's storybooks are written with various purposes-providing entertainment, information, empathy, style, and quality [3], and education, conveying a treasure of literature, encouraging understanding, providing cultural values, and sharing experiences, as well as stimulating the development of the mind [4].

In Indonesian context, children storybooks are commonly obtained by borrowing books from school libraries and public libraries, and only small number of people (children) purchase storybooks from bookstores. School and public libraries become the choices because buying books is not the top priority of people.

Libraries in Indonesia provide collections of children books for children, however, the collections are dominated by Indonesian storybooks. Taking this condition into account, and 
considering the poor reading interest of local children in Solo, Ganesa Library (GL) was then established by Debra and his husband to help improve local people's reading interest. This library is located in Sukoharjo, which is close to the city of Solo. This reading center has around 1,000 collections of English children stories that can be enjoyed by readers every day for free [5]. Since the readers are mostly children and they have limitations in understanding English stories, GL then takes an effort to bridge the needs of children readers by providing the Indonesian translations. This effort is carried out by involving internship students, majoring in English, from a number of universities in Solo and the surrounding areas. Their translations are put in empty spaces on the same pages of the English versions.

Translating children's storybooks is not a simple task, even though children's stories come with their "simplicity" of narrative and discourse levels [6], signalized with the utilization of uncomplicated characters, straight and linear plots, familiar settings, and simple language that is easy to understand [7]. This mission does not only cover the activities of rewriting in the target language (TL) at different times, places and cultures [8], but also includes the translators' attitude towards TL and culture of the target readers [9]. Attention needs to be given to the message and the stages of text form [10]. Further, specific items - stylistic features and greeting models that are appropriate for particular age groups - are certainly important [11].

One important aspect of translation quality is the naturalness. The concept of naturalness of translation develops over the changing time and the terms used by experts are varied, but the core definition remains identical. Translation is natural when it does not appear like a translation. Natural translation, thus, produced by referring to the receptor-oriented approach that considers adaptation of grammar, lexicon, and cultural references [12]. Naturalness is also defined as a natural usage comprises a variety of idioms or styles of registers determined primarily by the setting, where it is typically published, of the text and then the author, topic, and readership, exemplifying that a translation is natural when it is acceptable and uses common words in TL [13]. Another definition of naturalness shares to the concept of "fluency" and "invisibility", which suggests that naturalness is characterized by being modern, widely used, standard, and consistent in its variety [14].

Presenting natural translation is challenging for it requires profound decision-making [15]. Since naturalness is reader-oriented, this can be evaluated at both macro and micro structural levels [16]. The degrees of appropriateness in target text (TT), including a particular word, a cohesive device, a collocation, distribution of information, and text-typological convention, are some of the indicators [15]. Further, naturalness, particularly of literary translation, is indicated in a number of noticeable features, comprising well-formedness, acceptability, idiomacity, authenticity, and contemporaneity. Well-formedness requires TT be consistent with TL grammar rules and free from SL syntactical interference. Acceptability deals with the compliance with the target linguistic and cultural norms. Idiomacity is characterized as the tendency to use particular established formulas in TL cultures, such as collocations, idioms, and proverbs. Authenticity covers the exploitation of authentic language that utilizes TL rhetoric and aesthetic canons, as well as maintain an equilibrium between the natural flow of content and literariness. In other words, it should not exhibit any awkwardness or strangeness of grammatical of stylistic forms in TL [17].

Naturalness can pass through and be examined through various levels of translation, from word to textual levels [15]. Naturalness at lexical level demands proper dictions - choices of vocabularies - and transfer of connotative meaning of SL words into TL. Naturalness entails that one word may be appropriate in a given context, whereas even its synonyms are not. At sentence level, natural translation needs well-formed sentence in TT, and the sentence is SL requires to be restructured in line with the rules of TL syntax [18]. At cohesive level, naturalness 
requires inter-related elements and compact, powerful, and smooth text with natural flow, and therefore, it cannot be achieved through literal translation. Naturalness at idiomatic level implies that collocations, idioms and proverbs should be incorporated in a complete expression, instead of being used as a free-word combination.

A number of studies on the translation of children's literature have been performed with attentions on ideology and cultural adaptations [19], the comparison of quality of translation produced by professional translators and machine translations [20], the techniques and translation quality of fables [8], strategies in translating cultural terms and rendering text styles [21], challenges and obstacles encountered by novice translators in translating linguistic and cultural aspects [22], and translators' techniques in retaining the beauty of poetic children stories [23].

The absence of studies that examine the naturalness of children's storybook translation produced by novice translators encourages the researchers to investigate more thoroughly about the naturalness of translation resulted by student translators in GL. This study is significant because though their translation products have benefited thousands of the visitors of GL, the quality remains under questions because the translators are indeed learners, who have limited competences - bilingual, extra-linguistic, strategy, knowledge, and technological [24] — and experiences in industry. The present study explores the language naturalness of translation, by raising the issues on (1) how is the extent of language naturalness of the children's storybook translation produced by interns in GL and (2) what factors influence the level of language naturalness of the translations.

\section{Method}

This descriptive qualitative study was carried out through three main stages, including data collection, data analysis, and conclusion drawing. Data were obtained from documents and informants. The first data sources were 14 English-language children's storybooks and their translation in Indonesian produced by internship students at GL from 2010 to 2020 . The second sources were informants - data validator and raters of language naturalness level. The linguistic data were words, phrases, clauses, and sentences in ST and their translations in TT. Meanwhile, the other data were the information from the raters regarding naturalness assessment. Further discussion was conducted by comparing the results of researchers' assessment and raters' assessment in order to obtain more valid evaluation. The evaluation on the naturalness of translation was performed by using the indicators summarized from the theories and concepts proposed by the experts discussed in this paper. The data analysis was performed by mapping out the results of the assessment into three categories, including natural, less natural and unnatural. Further analysis was carried out with regard to the opinion of the raters accompanying the results of the translation. Factors that might affect the degree of naturalness were determined based on the existing phenomena. The conclusion was drawn by connecting the relationship of the degree of naturalness to the factors influencing the naturalness.

\section{Findings and Discussion}

\subsection{The naturalness of the translation of children's story books rendered by interns in the Ganesa Library}

The analyses on the translation resulted in three categories of translation naturalness, including natural, less natural, and unnatural translation. The levels of naturalness in this study occur at lexical into cohesion levels. 


\section{Natural translation}

A translation is natural when it does not sound like a translated work, meaning that the dictions are proper and familiar for the readers in the target language and the words, phrases, and sentences meet the grammatical system of the target language. Moreover, the text is compact, powerful and smooth, having natural flow of content [17]. A total of $34.56 \%$ of the translation falls into natural translation category. The followings are the instances of natural translation produced.

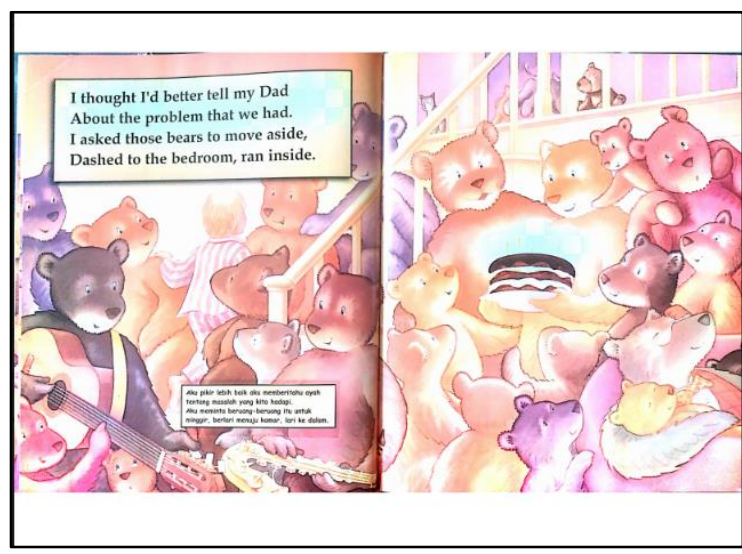

Fig 1. Example 1 (taken from "Bears")

ST: I climbed in bed and tried to sleep...

TT: Aku naik ke tempat tidur dan mencoba untuk tidur...

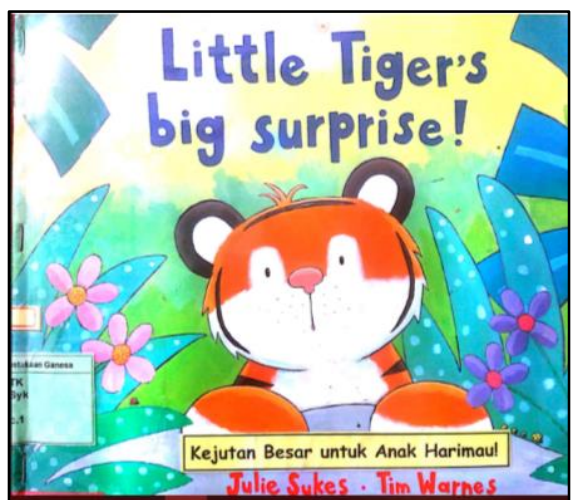

Fig 2. Example 2 (taken from "Little Tiger's Big Surprise")

ST: Little Tiger's Big Surprise

TT: Kejutan Besar untuk Anak Harimau 
In Example 1, the experiences in the ST are expressed in simple dictions "climbed in bed" and "tried to sleep". The ideas are also naturally and logically expressed in TL with simple dictions and are suitable with the context of situation, "naik ke tempat tidur" and "mencoba untuk tidur". Another instance of natural translation is obvious in Example 2, which shows the proper choices of dictions for the title of the storybook. The whole story tells about the big surprise given for the little tiger, the main character in the story. The title of ST "Little Tiger's Big Surprise" is conveyed into "Kejutan Besar untuk Anak Harimau", which means "Big Surprise for the Little Tiger", in TT. The translation is natural in terms of language use, particularly the grammatical rules and the logical meaning produced in TT. Instead of following the SL rules, the translator considers the context of situation built in the story, and prefers making a shift in word orders to make the TT more natural. The use of "untuk (to)" bridges the phrases "Kejutan Besar" and "Anak Harimau", and the use of "Anak Harimau (kid)" is more natural than "Harimau Kecil (small)", because in the story, "little" represents the member of a family, instead of the size of body.

\section{Less natural translation}

In less natural translation, some of the translation is acceptable, however, there are still several uses of less acceptable dictions or a little portion of grammatical errors in the target language in the rest of the translation. As a consequence, the delivery of TT produced is less compact and smooth [17]. Less natural translation is identified in $31.58 \%$ of the data. These are the examples of less natural translation noticed in the text.

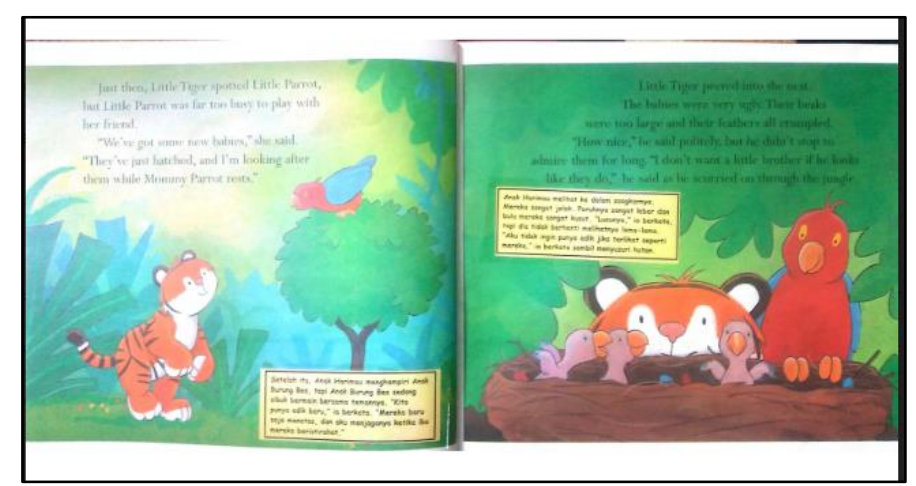

Fig 3. Example 3 (taken from "Little Tiger's Big Surprise")

ST: "They've just hatched, and I'm looking after them while Mommy Parrot rests." TT: "Mereka baru saja menetas, dan aku menjaganya ketika ibu mereka beristirahat." 


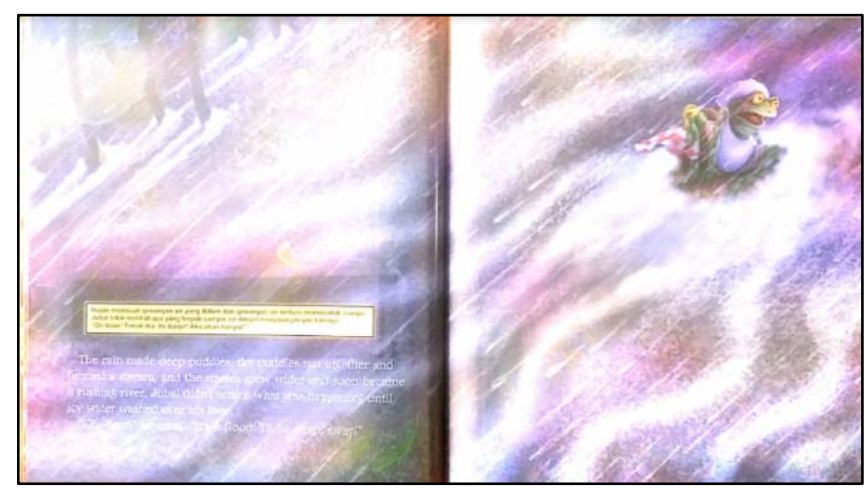

Fig 4. Example 4 (taken from "Jubal's Wish”)

ST: Jubal didn't notice what was happening until the icy water washed over his feet.

TT: Jubal tidak melihat apa yang terjadi sampai air dingin menyapu jari-jari kakinya.

Example 3 is a conversation taken from "Little Tiger's Big Surprise" book. In the dialogue, the Little Tiger perceives that the parrot's eggs have just hatched and he helps looking after the parrot's kids while the mother parrot has a rest. In TT, the sentence feels less natural due to inconsistent uses of pronouns that represent the same things. "Mereka" is natural for replacing "they", but "-nya" is not in line with the other pronouns because "-nya" is commonly used for substituting "his" or "her". The more natural translation is "Mereka baru saja menetas, dan aku menjaga mereka ketika ibu mereka beristirahat." In Example 4, taken from "Jubal's Wish", less natural translation is obvious in the conveyance of "didn't notice" into "tidak melihat (didn't see)". The context of situation built in the story is that Jubal was unaware of the coming flood because he was busy thinking about his problem. The more acceptable translation for the filament of the story is "tidak menyadari (didn't realize)".

\section{Unnatural translation}

A translation is considered unnatural when it sounds like a translated work. These are commonly signalized by the uses of dictions that are not common for readers, and words, phrases, as well as sentences that do not follow the grammatical rules of the target language. At the cohesive level, the TT is not compact and the ideas are delivered with peculiar flow of content [17]. A total of $33.84 \%$ ST are translated unnaturally into TT. These two examples depict the unnatural translation produced by the novice translators.

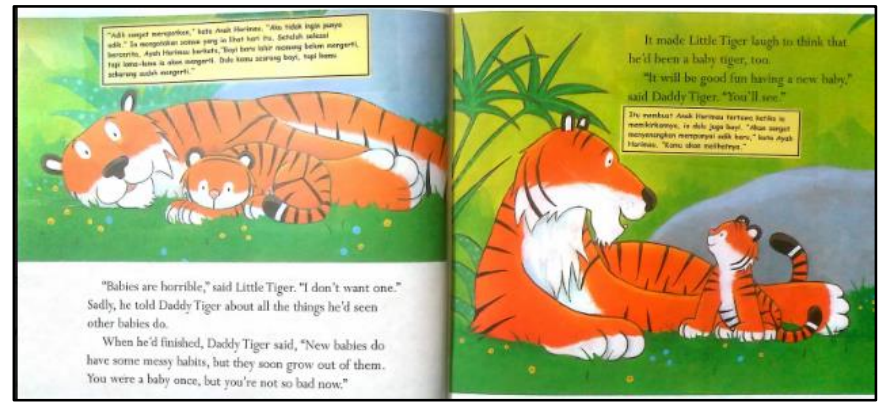

Fig 5. Example 5 (taken from “Little Tiger's Big Surprise”) 
ST: "It will be good fun having a new baby," said Daddy Tiger.

TT: "Akan sangat menyenangkan mempunyai adik baru, kata Ayah Harimau.

ST: "You'll see."

TT: "Kamu akan melihatnya."

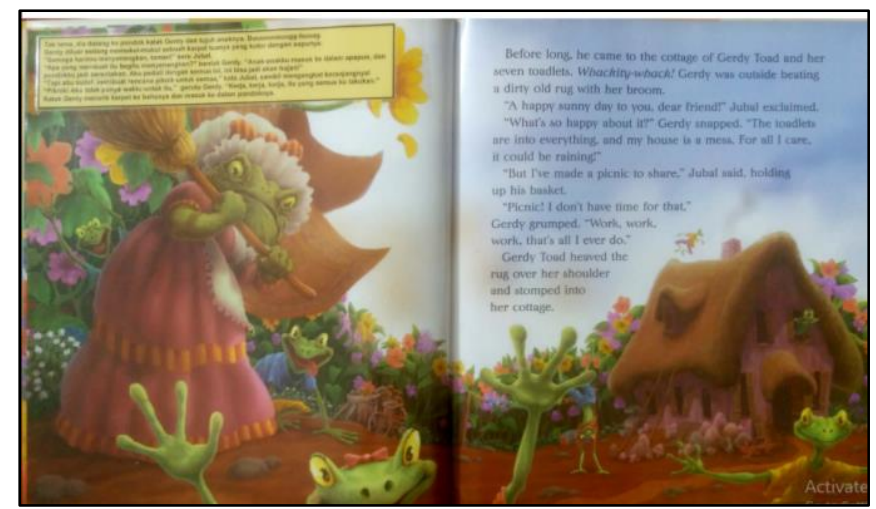

Fig 6. Example 6 (taken from "Jubal's Wish")

ST: "What's so happy about it?" Gerdy snapped. "The toadlets are into everything, and my house is a mess. For all I care, it could be raining!"

TT: “Apa yang membuat itu menyenangkan?” bentak Gerdy. “Anak-anakku masuk ke dalam apapun, dan pondokku jadi berantakan. Aku peduli dengan semua ini, ini bisa jadi akan hujan!"

In Example 5, Daddy Tiger says to his son "You'll see" and his expression means "You will prove it one day that having little brother or sister is exciting". However, the expression is literally rendered into "Kamu akan melihatnya". This translation falls into unnatural category because the expression in TT sounds unsuitable for convincing the little tiger. The recommended translation is "Кати akan membuktikannya," which means "You will prove it." Literal translation is also applied in Example 6. Most parts of the translation are unnatural and feel like translation, incorporating the structure as well as the literal meanings of words in ST. In the story, Gerdy questioned his friends for considering her condition of having kids playing around is good. She hoped that rain would soon come so that the rain would clean up her house after his kids made it so dirty. "What's so happy about it?" is literally translated into "Apa yang membuat itu menyenangkan?" and leave "the sentence" not in line with the function. Further, "The toadlets are into everything...", which contains idiom "into everything" that means "are interested doing everything", is literally rendered into "Anak-anakku masuk ke dalam apapun...", causing the expression unnatural. The translation of the last sentence, "Aku peduli dengan semua ini, ini bisa jadi akan hujan!", can be said illogical in terms of the delivery of idea and bound to the structure of ST sentence, making the message difficult to be interpreted. The translation is more natural if the TT is changed into " "Apa yang menyenangkan?" bentak Gerdy. "Anak-anakku tertarik bermain ini dan itu, dan rumahku jadi berantakan. Aku sangat berharap hari ini hujan lebat!” 


\subsection{The factors underlying the naturalness of the translation of the children's story books}

The discussion on the degree of translation naturalness in the previous part leads the researchers to notice several factors underlying the degree of naturalness of translation produced by novice translators in GL.

A number of natural translations have been produced and these have been achieved in the cases of rendering titles (see Example 2), names of food, names of objects, as well as common saying verbs and sentences with simple or less complicated ideas (see Example 1). Here are some of the cases.

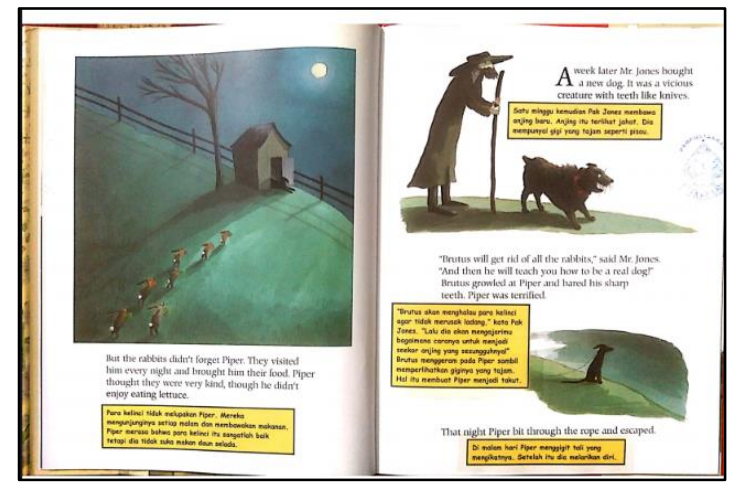

Fig 7. Example 7 (taken from "Piper")

ST: A week later Mr. Jones bought a new dog.

TT: Satu minggu kemudian Pak Jones membawa anjing baru.

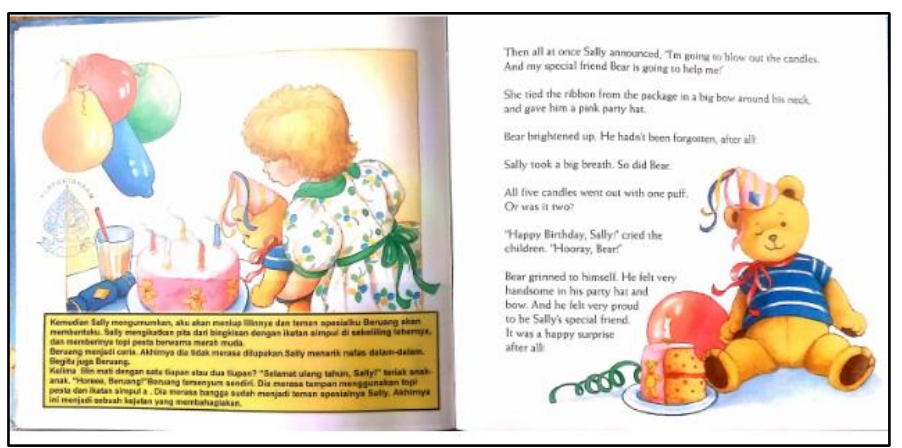

Fig 8. Example 8 (taken from "Birthday Bear")

ST: "Happy birthday, Sally!" cried the children. "Hooray, Bear!"

TT: "Selamat ulang tahun, Sally!" teriak anak-anak. "Horeee, Beruang!"

In Example 7, the idea of experience shared in the ST is as simple as the sentence structure, and therefore, this sentence can be rendered with equivalent idea, common dictions and sentence structure. In Example 8, saying verb "cried" in ST is acceptably and contextually conveyed into "teriak" in TT, instead of literally "menangis". Interjection "Hooray" is conveyed into "Horeee", with equal function and form, by applying naturalized borrowing. 
In spite of the fact that some of translation results are considered natural, more cases of both less natural and unnatural translation are found in the TT. The issues in the naturalness take place and are attributable to various linguistic and cultural aspects.

Linguistic aspect

Problems in naturalness come about in lexical, sentential, and cohesion levels. The causes of unnaturalness scrutinized in this study are (1) the use of unacceptable expression, (2) the use of sentences that remain applying the grammatical rules of SL, (3) the use of improper dictions that are not suitable with the context of situation built in the story, (4) the use of incomplete sentences, (5) the use of unparalleled words, (6) the use wrongly-ordered words in a sentence, (7) the use of general term resulting in unclear meaning, (8) the less logical or illogical delivery of experiences in the story, (9) the use of less simple words, (10) improper use of pronouns, as well as (11) improper use of particular saying verbs. The following depictions give detailed images of the contribution of those factors to less natural and unnatural translation.

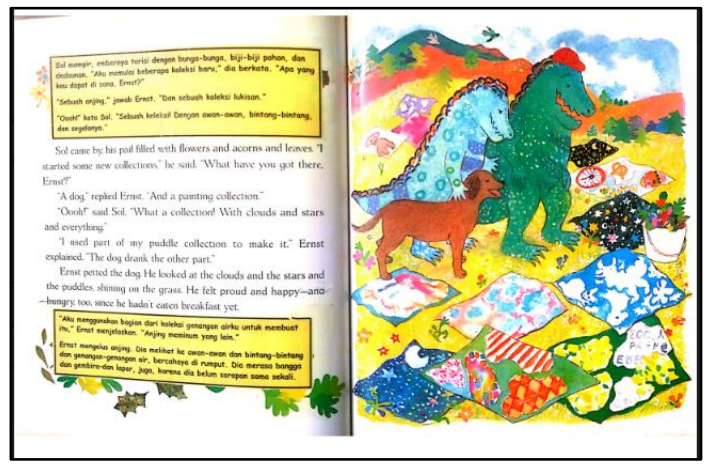

Fig 9. Example 9 (taken from "The Puddle Pail”)

ST: "What a collection! With clouds, stars and everything."

TT: "Sebuah koleksi! Dengan awan-awan, bintang-bintang, dan segalanya."

A compliment "What a collection" in Example 9 is translated literally into "Sebuah koleksi!" The expression in TT does neither match with the context of situation built in the conversation nor show any complimenting intention, leaving the expression peculiar because the translation produced tends to be more informative than expressive. The proper translation will be "Wah, koleksinya keren!" to praise a good collection. It is worth noting that one word may be appropriate in a given context while its synonyms are not proper to be incorporated in similar context [17]. This case is obvious in the improper choice of diction, "segalanya", for replacing "everything". It is true that "segalanya" is one of several words, such as "semuanya" and "apapun", in TL equivalent to "everything". However, in this context, "segalanya" is unnatural to show a collection. The alternative with proper nuance is "masih banyak lagi" or "semuanya". 


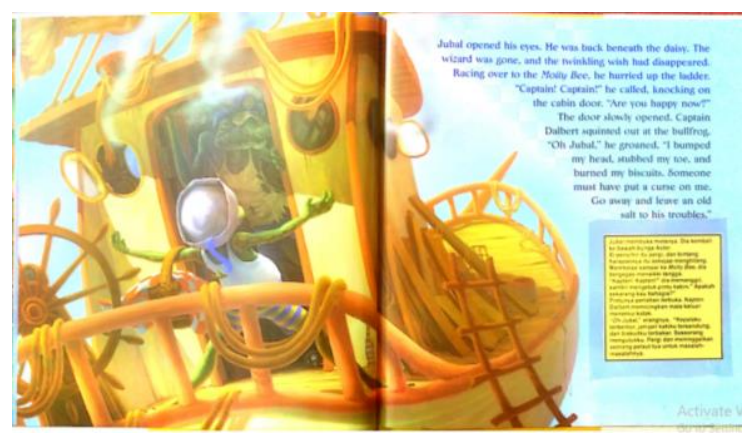

Fig 10. Example 10 (taken from "Jubal's Wish")

ST: "I bumped my head, stubbed my toe, and burned my biscuits. "Go away and leave an old salt to his troubles."

TT: "Kepalaku terbentur, jari-jari kakiku tersandung, dan biskuitku terbakar. Pergi dan meninggalkan seorang pelaut tua untuk masalah-masalahnya."

Taking a look at Example 10, we can see the unacceptable uses of expressions in TT. In the concept of people in TL, saying "jari-jari kakiku tersandung" is unusually used to show that the toe is bleeding or hurts after stumbling something. The expression "jari-jariku terantuk" is more acceptable in TT. The identical case is also noticeable in the translation of "burned my biscuits" into "biskuitku terbakar". It is uncommon in TL to express "biskuitku terbakar" because "terbakar" is usually put together with other objects, instead of food. The word "gosong" is more natural to come together with food, to show the condition that the food is burned and no longer edible. Also, both "go away" and "leave" are parallel in structure and used for imperative sentence. However, these aspects seem to be undetected by the translator. The words are translated into "pergi dan meninggalkan", which are not parallel in structure and "meninggalkan" does not function to ask, but to inform. The more acceptable translation will be "Pergi dan tinggalkan pelaut tua yang penuh masalah ini."

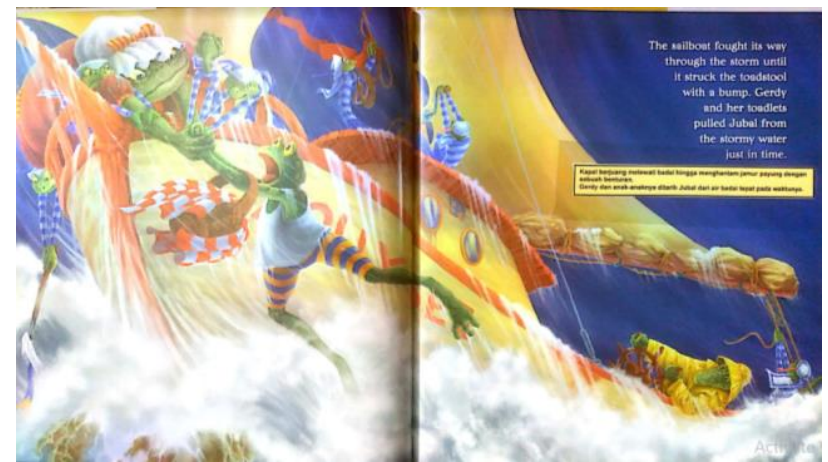

Fig 11. Example 11 (taken from “Jubal's Wish”)

ST: Gerdy and her toadlets pulled Jubal from the stormy water just in time.

TT: Gerdy dan anak-anaknya ditarik Jubal dari air badai tepat pada waktunya. 
Changes in the context of situation occur in Example 12. In ST, Gerdy and the toadlets helped Jubal by pulling him from stormy water. However, this scene is contradictory in TT, changing into "Gerdy dan anak-anaknya ditarik Jubal dari air badai...", which means that Jubal saved Gerdy and the toadlets. This surely contributes to unnatural translation. Moreover, the rendition of "stormy water" into "air badai" seems literally carried out, without considering common term used in TL. In TL, "air badai" is scarcely used, and the common term is merely "badai". Thus, the natural translation for this sentence is "Gerdy dan anak-anaknya menarik Jubal dari badai tepat pada waktunya".

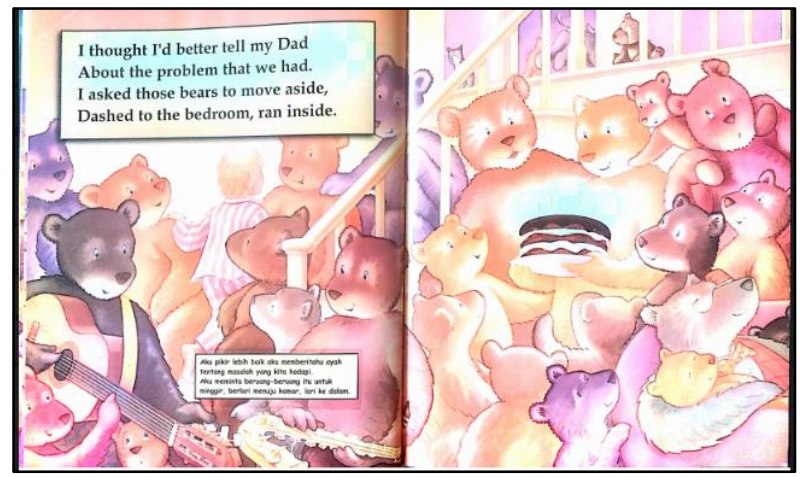

Fig 12. Example 12 (taken from "Bears")

ST: I thought I'd better tell my Dad about the problem that we had.

TT: Aku pikir aku lebih baik memberitahu Ayah tentang masalah yang kita hadapi.

Example 12 depicts other factor causing less natural translation. "I thought I'd better tell my Dad..." is translated into "Aku pikir aku lebih baik memberitahu Ayah...", and the Indonesian version seems following the SL grammatical rule and structure, causing the translation less natural. In fact, "Kurasa lebih baik aku memberitahu Ayah..." or "Sebaiknya aku memberitahu Ayah..." sounds more acceptable than the previous one.

\section{Cultural aspect}

Cultural aspects deal with the uses of expressions at idiomatic level, for examples, collocations, idioms, and proverbs, which need to be used in a particular combination, instead of in a free-word order. In some translations, however, problems in using those elements take place, which are mostly due to to the use of literal translation. 


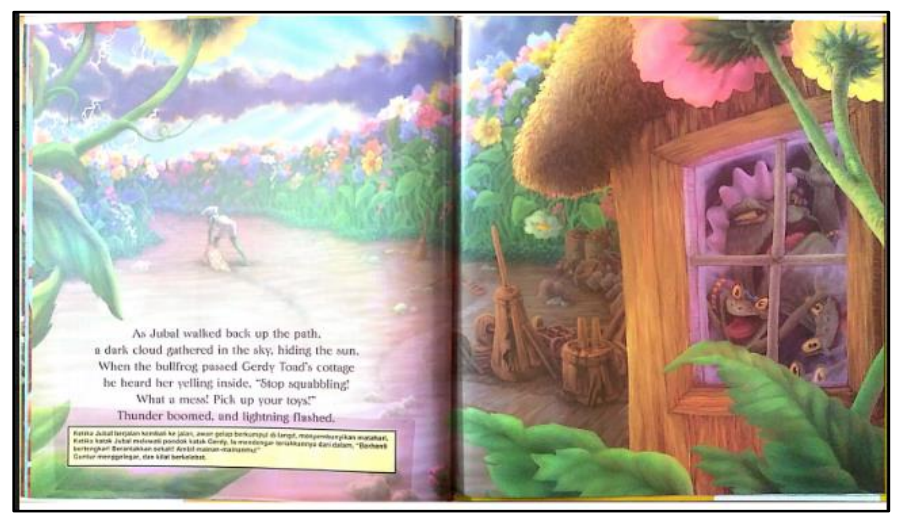

Fig 13. Example 13 (taken from “Jubal's Wish”)

ST: Thunder boomed, and lightning flashed.

TT: Guntur menggelegar, dan kilat berkelebat.

Example 13 depicts the problem of improper use of collocation in TT, "kilat berkelebat" as the correspondence of "lightning flashed". In TL, "kilat" usually comes together with "menyambar", instead of "berkelebat".

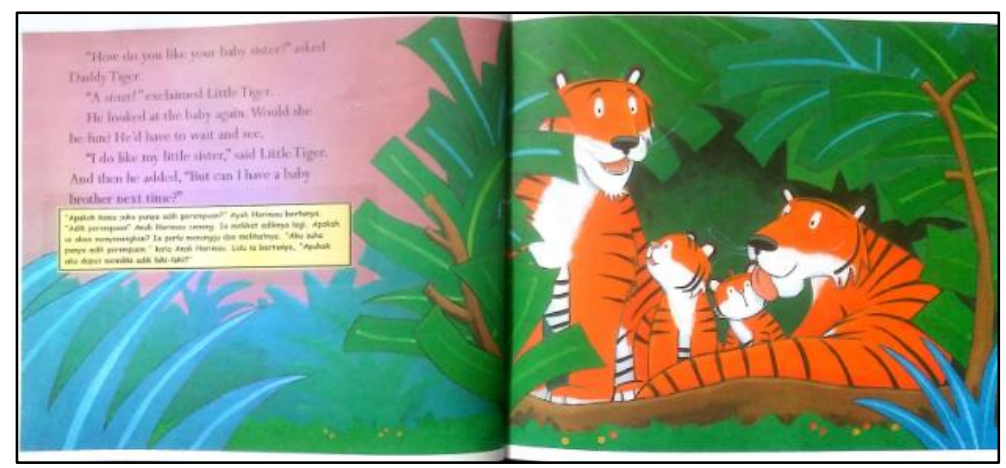

Fig 14. Example 14 (taken from "Little Tiger's Big Surprise")

ST: He'd have to wait and see.

TT: Ia perlu menunggu dan melihatnya.

The ST in Example 14 contains an idiom "wait and see" that connotes "be patient and do not worry about what is going to happen in the future because they have no control over it" [25]. This expression is literally rendered into "menunggu dan melihatnya". The translator seems insensitive with the use of this word combination and tends to consider the meanings of the words separately. Considering the context of situation, the natural translation should be "menunggu dan bersabar". 


\section{Conclusion}

This paper concludes that the translations of children's storybooks from English into Indonesian produced by the intern students in GL are mostly both less natural and unnatural. The cases happen due to both linguistic and cultural aspects. The linguistic factors cover the use of unacceptable expression, the use of sentences that remain applying the grammatical rules of SL, the use of improper dictions that are not suitable with the context of situation built in the story, the use of incomplete sentences, the use of unparalleled words, the use wrongly-ordered words in a sentence, the use of general term resulting in unclear meaning, the less logical or illogical delivery of experiences in the story, the use of less simple words, improper use of pronouns, as well as improper use of particular saying verbs, while the cultural factors deal with the problems in using expressions at idiomatic levels - collocations, idioms, and proverbs.

\section{References}

[1] Oittinen, R. Translating for children. New York and London: Garland Publishing, Inc.; 2000.

[2] Nurgiyantoro, B. Sastra anak: Persoalan genre. Humaniora. 2004; 16(2): 107-122.

[3] Chang, J.F. The role of children's literature in the teaching of English to young learners in Taiwan. Thesis. University of Waikato.

[4] Alivand, S. Children literature and translation: Purpose paradigm as a case in point. Translation Journal. 2016.

[5] Saputra, M.R. Debra Lunn dan Michael Mrowka, ibu dan bapak perpustakaan Ganesa Gentan. 2018.

[6] Nikolajeva, M. Children's literature comes of age. Toward a New Aesthetic. Abingdon: Routledge; 1996.

[7] Thompson, P. Sealey, A. Through children's eyes: Corpus evidence of the features of children's literature. International journal of corpus linguistics. 2007; 12(1): 1-23. Amsterdam: John Benjamins.

[8] Rohana, Santosa, R. Djatmika. Gaya bahasa, teknik penerjemahan, dan kualitas terjemahan dalam dongeng Disney dwibahasa berjudul "Cinderella: My Bedtime Story" dan "Tinkerbell and The Great Fairy Rescue". Prasasti: Journal of Lingistics. 2017; 2(1). Post-graduate Program. Universitas Sebelas Maret.

[9] Stolze, R. Translating for children-world view or pedagogics. Meta: Translators' Journal. 2003; 48(1-2): 208-221.

[10] Malmkjær, K. What happened to God and the angels: An exercise in translational stylistics. Target. International Journal of Translation Studies. 2003; 15(1): 37-58. Amsterdam: John Benjamins.

[11] Lathey, G. The translation of literature for children. In K. Malmkjær \& K. Windle (Eds.), The Oxford handbook of translation studies. 2011: 198-213. Oxford: O U P.

[12] Nida, E. Taber, C. The theory and practice of translation. Leiden: E. J. Brill; 1969: 323

[13] Newmark, P. A Textbook of translation. London: Prentice Hall; 1998: 292.

[14] Venuti, L. The translator's invisibility. London \& New York: Routledge. 1995.

[15] Rogers, M. Naturalness and translation. SYNAPS. Fagsprak, Kommunikasjon, Kulturkunnskap. 1999; 2(99): 9-31.

[16] Lambert, J. Van Gorp, H. On describing translation, in the manipulation of literature: Studies in literary translation, ed. by T. London: Croom Helm. 1985.

[17] As-Safi, A. Ash-Sharifi, I.S. Naturalness in the literary translation. Babel. 43: 160-75

[18] Nida, E. Language, structure and translation. California: Stanford University Press; 1975: 219

[19] Asiain, T. The translation of children's literature: Ideology and cultural adaptations. Captain Underpants as a case study. University of West of England. 2016

[20] Suprapto, D. Perbandingan hasil penerjemahan buku cerita anak-anak dongeng Danau Toba dari bahasa Indonesia ke bahasa Inggris melalui penerjemah dan mesin penerjemah. 
[21] Kujundzic, N. A journal of literature, culture and literary translation. 2018

[22] Nuraeni, A. Saptaningsih, N. Makmun, M.T. Penerjemahan buku cerita anak bergambar: Tantangan dan kendala menerjemahkan aspek linguistik dan budaya oleh mahasiswa prodi D3 Bahasa Inggris di Perpustakaan Ganesa. "Proceedings of the Fifth Prasasti International Seminar on Linguistics (PRASASTI 2019)". 2019

[23] Saptaningsih, N. Nuraeni, A. Uncovering the translators' techniques in retaining the beauty of poetic children stories. Advances in Social Science, Education and Humanities Research (ASSEHR), Volume 279, 300-313. Atlantis Press. Proceedings of Third International Conference of Arts, Language and Culture (ICALC 2018). 2018

[24] PACTE. Building a translation competence model in Alves, F. (ed.). Triangulating translation: perspective in process oriented research, Amsterdam: John Benjamin. 2003

[25] Collin dictionary [Internet]. 2020. Wait and see; [Cited 2020 May 25]; [about 1 screen]. Available from https://www.collinsdictionary.com/dictionary/english/wait-and-see 